\title{
Correction: Control of PD-L1 expression by miR-140/142/340/383 and oncogenic activation of the OCT4-miR-18a pathway in cervical cancer
}

\author{
Peixin Dong ${ }^{1,2} \cdot$ Ying Xiong ${ }^{3} \cdot$ Jiehai $\mathrm{Yu}^{3} \cdot$ Lin $\mathrm{Chen}^{3} \cdot$ Tang Tao $^{4} \cdot$ Song $\mathrm{Yi}^{4} \cdot$ Sharon J. B. Hanley ${ }^{1}$ Junming Yue ${ }^{5,6}$. \\ Hidemichi Watari ${ }^{2} \cdot$ Noriaki Sakuragi $^{1}$
}

Published online: 24 January 2019

(c) The Author(s) 2019. This article is published with open access

\section{Correction to: Oncogene \\ https://doi.org/10.1038/s41388-018-0347-4; \\ Published online 31 May 2018}

In Fig. 2d, the Western blot panels representing GAPDH endogenous loading controls were improperly cropped, leading to four lanes of GAPDH endogenous loading controls for five lanes of PD-L1 protein expressions. The authors apologize for any confusion that this error may have caused. This has now been corrected in both the PDF and HTML versions of the article.
Open Access This article is licensed under a Creative Commons Attribution 4.0 International License, which permits use, sharing, adaptation, distribution and reproduction in any medium or format, as long as you give appropriate credit to the original author(s) and the source, provide a link to the Creative Commons license, and indicate if changes were made. The images or other third party material in this article are included in the article's Creative Commons license, unless indicated otherwise in a credit line to the material. If material is not included in the article's Creative Commons license and your intended use is not permitted by statutory regulation or exceeds the permitted use, you will need to obtain permission directly from the copyright holder. To view a copy of this license, visit http://creativecommons. org/licenses/by/4.0/.
The original article can be found online at https://doi.org/10.1038/ s41388-018-0347-4.

Peixin Dong

dpx1cn@gmail.com

$\triangle$ Junming Yue jyue@uthsc.edu

$\bowtie$ Hidemichi Watari watarih@med.hokudai.ac.jp

1 Department of Women's Health Educational System, Hokkaido University School of Medicine, Hokkaido University, Sapporo 0608638, Japan

2 Department of Obstetrics and Gynecology, Hokkaido University School of Medicine, Hokkaido University, Sapporo 0608638, Japan
3 Department of Gynecology, State Key Laboratory of Oncology in South China, Sun Yat-Sen University Cancer Center, 510060 Guangzhou, China

4 Faculty of Medicine, Department of Obstetrics and Gynaecology, The Chinese University of Hong Kong, Shatin, New Territories, Hong Kong, China

5 Department of Pathology and Laboratory Medicine, University of Tennessee Health Science Center, Memphis, TN 38163, USA

6 Center for Cancer Research, University of Tennessee Health Science Center, Memphis, TN 38163, USA 